\begin{tabular}{|c|c|c|}
\hline \multirow[t]{2}{*}{7} & $\begin{array}{l}\text { International Journal of Current Research in } \\
\text { Biosciences and Plant Biology }\end{array}$ & 5 \\
\hline & Volume $5 \bullet$ Number $6($ June-2018) • ISSN: 2349-8080 (Online) & \\
\hline $\begin{array}{l}\text { EXCELLENT } \\
\text { PUBLISHERS } \\
\end{array}$ & Journal homepage: www.ijcrbp.com & nww.jusctposom \\
\hline
\end{tabular}

Original Research Article

doi: https://doi.org/10.20546/ijcrbp.2018.506.008

\title{
A Study on the Extraction of Essential Oil from Avocado and its Properties
}

\author{
R. Sri Padmapriya and Anita R.J. Singh* \\ PG \& Research Department of Biotechnology, Women's Christian College, Chennai - 600006 \\ Affiliated to the University of Madras, Chennai, Tamil Nadu, India
}

*Corresponding author.

\begin{tabular}{|c|c|}
\hline Article Info & ABSTRACT \\
\hline $\begin{array}{l}\text { Date of Acceptance: } \\
\text { 01 June } 2018\end{array}$ & \multirow{3}{*}{$\begin{array}{l}\text { Avocado (Persea Americana) also known as butter fruit has numerous medicinal } \\
\text { properties and is beneficial to health. The pulp and seed were extracted using } \\
\text { chloroform and ethanol. The phytochemical analysis determined the presence of } \\
\text { alkaloids, flavonoids, tannins and saponins. In avocado pulp, alkaloids and flavonoids } \\
\text { were present in a higher concentration and in seeds, cardiac glycoside and tannins } \\
\text { showed lower concentration. Macro molecules such as carbohydrates, proteins and } \\
\text { fatty acids were determined. In pulp and seed, fatty acid showed higher concentration } \\
\text { while proteins showed the lesser concentration in pulp and seed; carbohydrates } \\
\text { however were present in the same concentration. Phenolic contents, cholesterol and } \\
\text { amino acid were determined. Amino acid and phenolic content showed higher } \\
\text { concentration in case of pulp and seed whereas cholesterol was present in small } \\
\text { amount. The extraction of oil was carried out by means of cold extraction process . The } \\
\text { lipid profile of avocado oil was determined which included the estimation of } \\
\text { cholesterol, fatty acid, iodine number and saponification number. Iodine number was } \\
\text { high in pulp and seed. Fatty acid value and acid value were the same in pulp and seed. } \\
\text { Saponification number was also the same for seed and pulp. }\end{array}$} \\
\hline Keywords & \\
\hline $\begin{array}{l}\text { Avocado } \\
\text { Cold extraction } \\
\text { Ethyl lactate } \\
\text { Fatty acid } \\
\text { Macromolecule }\end{array}$ & \\
\hline
\end{tabular}

\section{Introduction}

Avocado originated from Central America and hence named "Persea Americana." It provides high quality oil which consists of Vitamin- A, E\& D which is beneficial for hair and skin. It contains lecithin, sterolins, and potassium, acts as booster for health as it penetrates and nourishes the skin. It helps in absorption of vitamins and nutrients, helps in the removal of skin related problems such as eczema, psoriasis, sun-burns, and skin blemishes. The skin of the avocado possesses an antioxidant activity to protect the skin from damage. It also acts as an antibiotic and used to cure dysentery. Avocado pulp helps in dissolving kidney stones which is due to lowering the amount of calcium in 
the urinary tract and helps in curing cancer as it induces apoptosis. Avocado contains Vitamin-A, $\mathrm{B}_{6}, \mathrm{C}, \mathrm{K}$ protein, copper, potassium and helps in the prevention of cataract in eyes and helps to overcome from Arthritis problems. Avocado seed turns red on exposure to air due to the presence of tannin. The seed contains a milky latex similar to the colour and odour of almond. The seed is used to treat hypercholesterolemia, hypertension, inflammation and diabetes. A small piece of avocado seed, boiled along with its leaves and consumed gives relief from toothaches. Avocado oil is used in the manufacturing of soap and in the cosmetic industry It is used as an antioxidant, anti-wrinkle, anti-bacterial agent and helps to lower blood pressure. Avocado seed oil is used against dryness and to prevent wrinkles in the skin. Avocados has lipids which are used in the treatment of Acute Myeloid Leukaemia (AML). The bioactive molecules from avocado help to fight blood cancer. Avocado oil should be stored in air tight container either glass or oil. It should be refrigerated in hot and humid area.

\section{Materials and methods}

\section{Phyto chemical analysis}

The dried extracts were ground into powder and mixed in solvents such as chloroform and ethanol. $10 \mathrm{gm}$ of pulp and seed were dissolved in $100 \mathrm{ml}$ of chloroform and ethanol respectively in conical flasks and covered with aluminium foil. They were placed in a rotatory shaker for 24 hours. The filtrate obtained from these extracts were used for further phytochemical analysis.

\section{Phyto chemical screening}

\section{Qualitative tests}

\section{1) Test for carbohydrates}

\section{Fehling's solution}

$10 \mathrm{ml}$ of Fehling's solution was added to the filterate and was kept in a boiling water bath for 510 minutes.

\section{2) Test for alkaloids}

Drangandroff Test:-A small portion of extracts was stirred separately with few drops of concentrated sulphuric acid and it was filtered. Drangandroff reagent was added to the filtrate.

\section{3) Test for proteins and amino acid}

(i) Biuret test:-To $3 \mathrm{ml}$ of the filtrate, $4 \mathrm{ml}$ of $10 \%$ $\mathrm{NaOH}$ (sodium hydroxide) and few drops of $1 \%$ of Copper sulphate.

(ii)Ninhydrin test:-To $1 \mathrm{ml}$ of the filtrate, $1 \%$ of Ninhydrin was added and heated in a water bath.

\section{4) Test for phyto sterols}

The extract was dissolved and $0.05 \%$ ferric chloride acetic acid was added followed by adding 1-2 drops of concentrated sulphuric acid along the sides of test tubes.

\section{5) Test for Flavonoids}

Alkaline Reagent Method:-To few drops of filtrate, few drops of sodium hydroxide was added. After it became yellow in colour a few drops of concentrated $\mathrm{HCl}$ was added.

\section{6) Test for Saponins}

Foam test:-To few drops of the filtrate, $5 \mathrm{ml}$ of distilled water was added and it was shaken vigorously.

\section{7) Test for Tannins}

i) Gelatin test:-Small quantity of extracts were taken and dissolved in water which was tested with $1 \%$ of Gelatin and $10 \%$ of Sodium chloride.

(ii) Lead acetate test:-Small quantity of extracts were taken and dissolved in water which was tested with $10 \%$ of lead acetate.

(iii) Ferric chloride test:-Small quantity of extracts was taken separately in water with dilute ferric chloride. 


\section{8) Test for Cardiac Glycoside}

Keller-Killani test:-To $2 \mathrm{ml}$ of the filtrate, few drops of glacial acetic acid, 5\% of ferric chloride and concentrated sulphuric acid were added.

\section{9) Test for fixed Fats and Oil}

Sudan black test:-To the few $\mathrm{ml}$ of the extracts, Sudan black was added.

\section{Quantitative Tests}

\section{Estimation of Carbohydrate (Anthrone Method)}

The pulp and seed samples was weighed and taken into boiling test tubes. $2 \mathrm{ml}$ of $1 \mathrm{~N}$ of $\mathrm{HCl}$ was added to the boiling test tube which was kept in a water bath for 3 hours or till the appearance of pink colour. Sodium carbonate was added to the test tube to obtain effervescence. Then added distilled water and made up the volume to $100 \mathrm{ml}$.

The supernatant was collected. The Blank (B) was prepared by adding water and Anthrone reagent. Standards were taken in the range of $0.2 \mathrm{ml}-1 \mathrm{ml}$. The volume was made up to $1 \mathrm{ml}$ in all the test tubes. The test tubes were placed in a boiling water bath and it was cooled rapidly till it turned from green to dark blue colour. Optical density was obtained at $630 \mathrm{~nm}$.

\section{Estimation of Alkaloid Content (Harborne Method)}

The samples (pulp and seed) were weighed and added to the beakers. Two hundred $\mathrm{ml}$ of $10 \%$ acetic acid in ethanol was added, covered and allowed to stand for 4 hours. It was filtered. Extracts were kept in a water bath till it was reduced to one-fourth of original volume. Concentrated ammonium hydroxide was added drop wise to the extract until the precipitate was obtained. The whole solution was allowed to settle and the precipitate was collected and washed with dilute ammonium hydroxide which was then filtered.

\section{Alkaloid content $=$ \\ $\underline{\text { Weight of Alkaloid extract }} \times \mathbf{1 0 0}$ Weight of sample (mg)}

\section{Estimation of proteins (Lowry's method)}

Standard solution $(0.2$ to $1.0 \mathrm{ml})$ was taken in test tubes. The extracted samples (pulp and seed) were taken in test tubes. The volume of water was made up to $1 \mathrm{ml}$ including the blank. $5 \mathrm{ml}$ of alkaline copper tartrate reagent was added to the all the test tubes. It was mixed and allowed to stand for 10 minutes. $0.5 \mathrm{ml}$ of Folin's reagent was added to test tubes including the blank. The test tubes were incubated at room temperature in dark for 30 minutes. The Optical density was read at $660 \mathrm{~nm}$.

\section{Estimation of Flavonoids}

The samples (pulp and seed) were taken and $100 \mathrm{ml}$ of $80 \%$ of aqueous methanol was added. The whole solution was filtered through Whatman filter paper. The filtrate obtained was transferred into a crucible and evaporated into dryness over a water bath.

\section{Estimation of Amino acid (Ninhydrin method)}

Standards were taken as $0.2 \mathrm{ml}$ to $1.0 \mathrm{ml}$ in the test tubes. Extracts of samples (pulp and seed) were also taken. The volume of distilled water was made up to $2 \mathrm{ml}$ in all the test tubes including the blank. $2 \mathrm{ml}$ of Ninhydrin was added to all the test tubes .The test tubes were kept in boiling water bath for 15 minutes. $3 \mathrm{ml}$ of ethanol was added to all the tubes. The optical density was read at 570nm.

\section{Estimation of Tannin (Poly Vinyl Pyrolindine method)}

$0.5 \mathrm{ml}$ of the extracts (Pulp and seed) were taken in the test tubes. $0.05 \mathrm{ml}$ of PVP (Poly vinyl pyrolindine) was added to the test tubes. $0.05 \mathrm{ml}$ of distilled water was added to both the extracts. It was incubated for 4 hours and it was centrifuged at $5000 \mathrm{rpm}$ for 5 minutes. The supernatant was removed and OD was taken at $725 \mathrm{~nm}$ in colorimeter. 


\section{Tannin $(\mathrm{mg} / \mathrm{g}$ extract $)=$ Total phenolic substance (mg/g)-Free phenolic substance (mg/g).}

\section{Estimation of total phenolic contents}

Standards were taken as $1.25 \mathrm{ml}$ to $6.75 \mathrm{ml}$ in the test tubes. The sample extracts (pulp and seed) were taken in test tubes. $0.5 \mathrm{ml}$ of Folin-Ciocalteau reagent was added to all the test tubes including the blank. $2.5 \mathrm{ml}$ of $20 \%$ of sodium carbonate was added to all the test tubes. The tubes were made up to $5.75 \mathrm{ml}$ with distilled water. The test tubes were incubated at room temperature for 2 hours. The optical density was determined at 760nm.

\section{Estimation of cardiac glycoside}

The powdered samples (pulp\& seed) were mixed in $50 \mathrm{ml}$ of $35 \%$ ethanol in conical flasks. The conical flasks were covered and placed in shaker for 6 hours. It was filtered to another flask.10 ml of distilled water and $20 \mathrm{ml}$ of $6.4 \%$ lead acetate were added. $45 \mathrm{ml}$ of distilled water was added and shaken well by placing it in a shaker for 10 minutes. To the precipitate formed $7.5 \mathrm{ml}$ of $2.38 \%$ distilled sodium hydrogen phosphate solution was added .The resultant solutions were filtered. To the filtrate added $1 \mathrm{mg}$ of dried extract, $1 \mathrm{ml}$ of glacial acetic acid and 2 drops of $1 \%$ of Ferric chloride solution.

\section{Cardiac glycoside $=$}

Weight of the dried extracts $\times \mathbf{1 0 0}$

Weight of dried ground sample

\section{Estimation of cholesterol (Zak's method)}

Standard solutions were taken in the range of 0.5 to $2.5 \mathrm{ml}$ in different test tubes. $0.2 \mathrm{ml}$ and $0.4 \mathrm{ml}$ of seed sample were taken in separate test tubes. $0.05 \%$ ferric chloride acetic acid reagent was added to make up the volume to $5 \mathrm{ml} .5 \mathrm{ml}$ of ferric chloride was used as the blank. $3 \mathrm{ml}$ of concentrated sulphuric acid was added to all the test tubes. The test tubes were incubated at room temperature for 10-20 minutes. The optical density was read at $570 \mathrm{~nm}$.

\section{Estimation of fatty acid}

The sample (pulp and seed) were taken in a conical flask.50ml of neutral solvent was added along with a few drops of phenolphthalein indicator. The $\mathrm{pH}$ was maintained at 8 by adding drops of $\mathrm{NaOH}$. Potassium hydroxide was taken in the burette and it was titrated against the sample. Appearance of pale pink colour was the end point.

\section{Thin layer chromatography}

\section{Detection of phenolic compound}

Chloroform: Methanol in ratio of 9:1 served as mobile phase. Folin- Ciocalteau reagent was used as spraying reagent. The sample (pulp and seed) were spotted on TLC plate.

\section{Detection of phyto-sterol}

The Thin layer chromatography was done using $10 \times 20 \mathrm{~cm}$. silica plate. Benzene and Methanol were used as a mobile phase. 5\% of alcoholic sulphuric acid was used as spraying agent. Appearance of bluish green colour indicated the presence of steroids.

\section{Detection of saponins}

Chloroform: Glacial acetic acid: Methanol: Water $(8: 4: 1.5: 6.5)$ was used as mobile phase. The plates were developed using Iodine vapours.

\section{Extraction of pulp and seed oil}

The pulp and seed were removed from Avocado. They were cut and ground into small pieces. They were made into juice using blender. After straining, they were sieved. The thick juice of pulp and seed were kept for overnight. After 24 hours, the top creamy layer was removed. In a clean pan, it was kept on a low flame and was allowed to heat until the proteins turned brown.

Lipid profile $-2.5 \mathrm{ml}$ of oil was diluted with $25 \mathrm{ml}$ of chloroform and used to analyses. 


\section{Estimation of cholesterol method (Zak's method)}

Standard solutions were taken in the range of 0.5 to $2.5 \mathrm{ml}$ in different test tubes. $0.2 \mathrm{ml}$ and $0.4 \mathrm{ml}$ of seed sample were taken in separate test tubes. $0.05 \%$ ferric chloride acetic acid reagent was added to make up the volume to $5 \mathrm{ml} .5 \mathrm{ml}$ of ferric chloride was used as the blank. $3 \mathrm{ml}$ of concentrated sulphuric acid was added to all the test tubes. The test tubes were incubated at room temperature for 10-20 minutes. The optical density was read at 570nm.

\section{Estimation of fatty acid}

The sample (pulp and seed) were taken in a conical flask.50ml of neutral solvent was added along with a few drops of phenolphthalein indicator. The $\mathrm{pH}$ was maintained at 8 by adding drops of $\mathrm{NaOH}$. Potassium hydroxide was taken in the burette and it was titrated against the sample. Appearance of pale pink colour was the end point.

\section{Acid value of oil}

The samples (pulp and seed) were taken in conical flask. $25 \mathrm{ml}$ of ethanol was added into the conical flask. It was shaken well and phenolphthalein indicator was added .The samples were titrated against $0.1 \mathrm{~N} \mathrm{KOH}$ which was taken in a burette. The faint pink colour was the end point which was persistent for 20-30 seconds. The Blank which was prepared without the test solution was titrated with $0.1 \mathrm{~N} \mathrm{KOH}$.

\section{Acid Value (mg KOH/g of fat) = Titre valuex Normality of $\mathrm{KOH} \times 56.1$ Weight of the sample (gm.)}

\section{Iodine value of oil}

$5 \mathrm{ml}$ of Wiji's solution was dissolved with a known amount of oil. It was shaken thoroughly and allowed it to stand in dark for 1hour. Blank solution was prepared without the oil. After 1 hour, the stopper and the neck of the Iodine flask was rinsed with $10 \mathrm{ml}$ of water and $2 \mathrm{ml}$ of Potassium Iodide was added. The liberated Iodide as titrated against sodium thiosulphate till the contents of the flask turned straw yellow in colour. The solution was continuously titrated against sodium thiosulphate solution till the blue colour disappeared.

\section{Iodine value $=(x-y)=\quad \underline{12.7 \times 100}$ $1000 \times$ weight of the sample}

\section{Saponification of Oil}

One gram of pulp and seed oil was weighed accurately and dissolved in $3 \mathrm{ml}$ of fat solvent. $25 \mathrm{ml}$ of $0.5 \mathrm{~N}$ alcoholic $\mathrm{KOH}$ was added. It was attached into a reflux condenser and the contents of boiling water bath for 30 minutes. It was cooled at a room temperature and few drops of phenolphthalein were added. The blank was refluxed with $25 \mathrm{ml}$ or $0.5 \mathrm{~N}$ alcoholic $\mathrm{KOH}$ without the fat sample. The contents of the flask were titrated till the pink colour disappeared.

\section{Saponification value $=\underline{28.05} \times$ Titre value Weight of the sample (g)}

\section{Identification of saturated and unsaturated fats}

The pulp and seed oil was kept in refrigerator to check for solidification to determine the level of saturation.

\section{Cytotoxicity studies-(MTT ASSAY)}

\section{Stock concentration}

$1 \mathrm{mg}$ of sample was dissolved in $1 \mathrm{ml}$ of serum free MEM/DMSO (Dimethyl sulphoxide). The stock was freshly prepared and filtered through $0.45 \mu$ filter before each assay.

\section{Preparation of working standard}

To $1 \mathrm{ml}$ of MEM (Minimal Essential Media) without serum concentration, DMSO (dimethyl sulphoxide) was added to $1 \mathrm{ml}$ of sample as a working concentration. The sample concentration ranging from $1000 \mu \mathrm{g}$ to $7.8 \mathrm{mg}$ can be prepared from the working stock was mad up to $1 \mathrm{ml}$. 
Vero Cell lines were plated in 24 well plates and incubated at $37^{\circ} \mathrm{C}$ with $5 \% \mathrm{CO}_{2}$ conditions. After the cell reached the confluences, media was removed without disturbing the cells. The procedure was repeated at various concentration of the samples. After incubation of the sample, it was washed with phosphate buffered saline at $\mathrm{pH}$ of 7.4. $100 \mu \mathrm{l} /$ well $(5 \mathrm{mg} / \mathrm{ml})$ of $0.5 \% 3-4$, 5dimethy-2thiazolyl-2, 5-phenyl-tetrazoiumbromide (MTT) was added.

After incubation, $1 \mathrm{ml}$ of DMSO was added to all the wells. The absorbance was measured at 570nm with UV spectrophotometer using DMSO. Measurements were performed and the concentration required for $50 \%$ inhibition was determined graphically. The percentage of viability of cells were determined by -

\section{$\%$ Cell Viability $=\underline{\mathrm{A570}}$ of treated cells $\times 100$ A570 of controlled cells}

\section{Results}

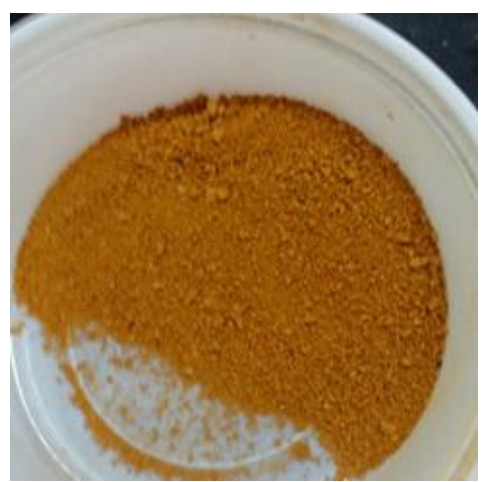

Fig.1: The powdered form of seed.

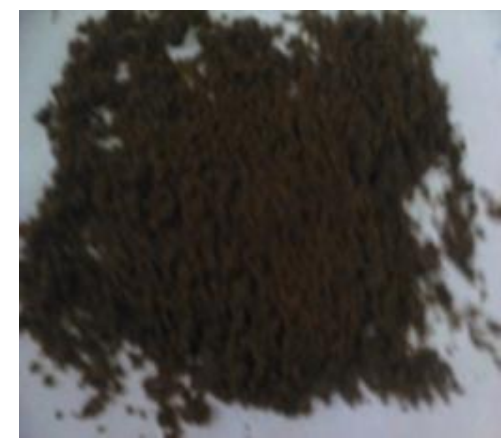

Fig.2: The powdered form of pulp.

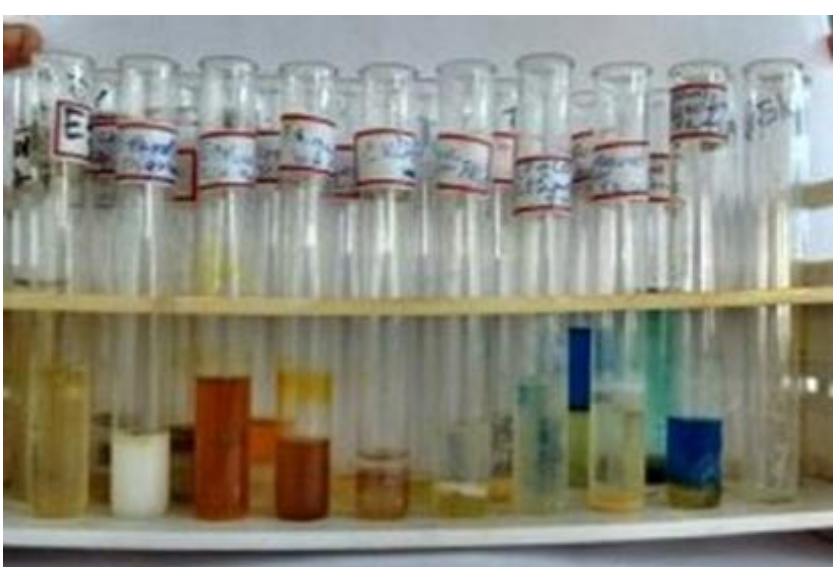

Fig. 3: Shows the results for the qualitative analysis of phytochemicals conducted on the pulp and seed of avocado.

Table 1. The qualitative analysis of phytochemicals in pulp and seeds of avocado.

\begin{tabular}{|c|c|c|c|c|}
\hline 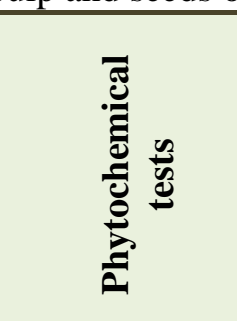 & 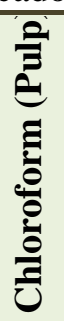 & 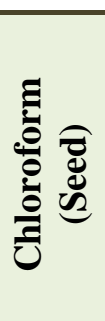 & 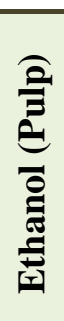 & 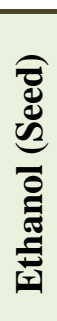 \\
\hline Carbohydrates & + & + & + & + \\
\hline $\begin{array}{l}\text { Proteins and } \\
\text { amino acid }\end{array}$ & + & + & + & + \\
\hline Fats and oil & + & + & + & + \\
\hline Tannins & - & - & + & + \\
\hline Alkaloids & + & + & + & + \\
\hline $\begin{array}{l}\text { Cardiac } \\
\text { glycoside }\end{array}$ & + & + & + & + \\
\hline Flavonoids & + & + & + & + \\
\hline $\begin{array}{l}\text { Phenolic } \\
\text { contents }\end{array}$ & + & + & + & + \\
\hline Phyto sterols & + & + & + & + \\
\hline Saponins & + & + & + & + \\
\hline
\end{tabular}

The phytochemical such as carbohydrates, proteins, amino acid, fats and oils, phenolic contents, saponins, flavonoids, Cardiac glycosides, and Alkaloids were present in pulp and seed except for tannins which was absent in chloroform extract. 


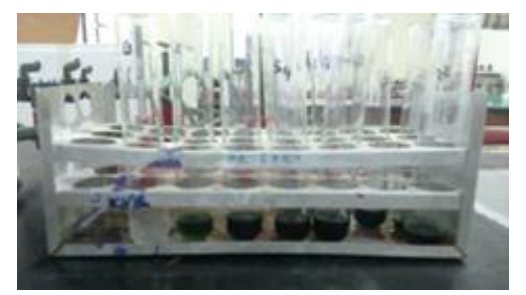

Fig. 4: Results for estimation of carbohydrate

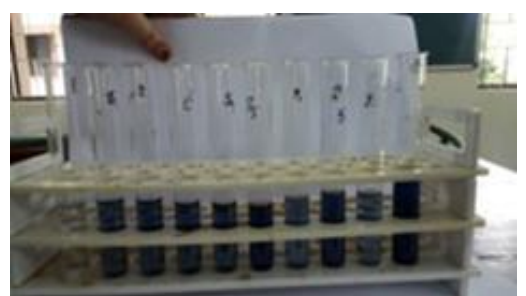

Fig. 5: Results for estimation of protein

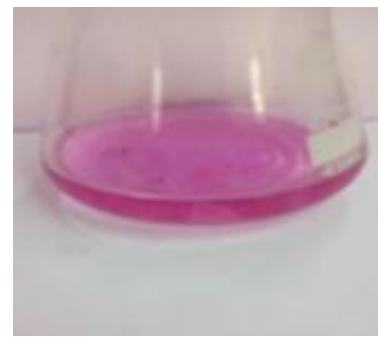

Fig. 6: End point for estimation of fatty acid

Table 2. Shows the result obtained for the estimation of Carbohydrate, Proteins and Fatty acid.

\begin{tabular}{lll}
\hline Estimation & Pulp $\mathbf{( m g )}$ & Seed $(\mathbf{m g})$ \\
\hline Carbohydrate & $38.3 \pm 04$ & $38.3 \pm 0.4$ \\
Proteins & $16.1 \pm 3.62$ & $22.5 \pm 2.27$ \\
Fatty acid & $312.5 \pm 4.4$ & $512.5 \pm 6.4$ \\
\hline
\end{tabular}

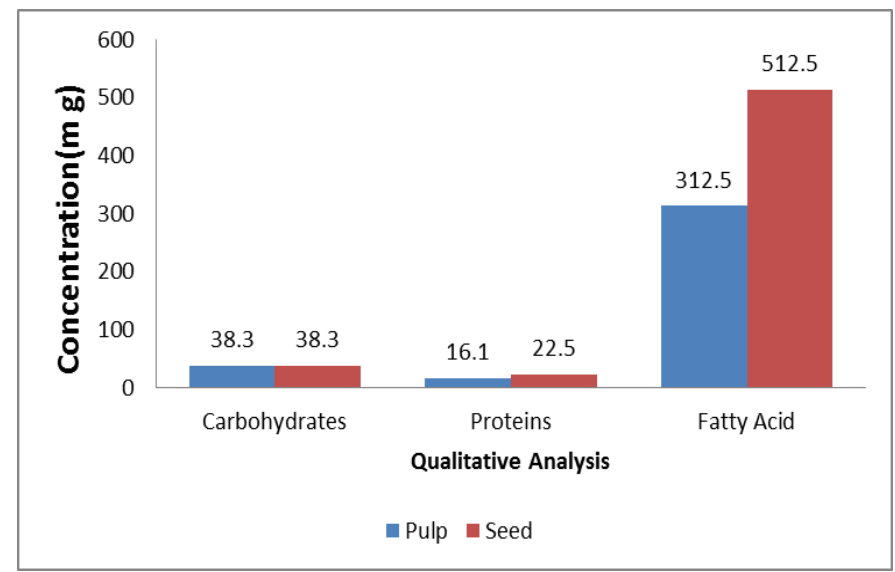

Graph 1. Illustrates the quantitative analysis of Carbohydrates, Proteins and Fatty acid indicating almost equal quantities of Carbohydrates in pulp and seed slightly higher concentration of proteins in seeds and very high in quantity in seed in comparison to pulp.

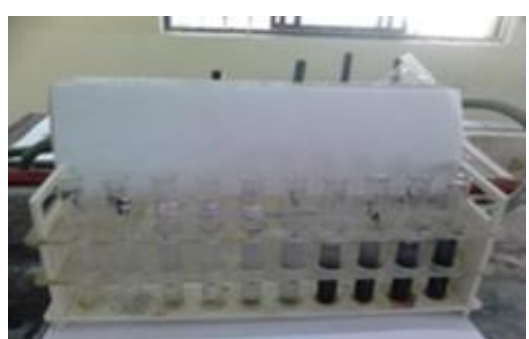

Fig. 7: Results for estimation of phenolic contents.

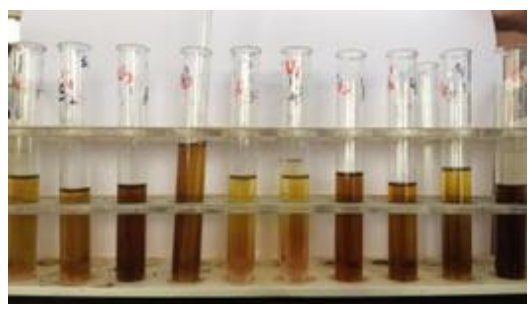

Fig. 8: Results for estimation of cholesterol.

Table 3. Shows the results for the estimation of Phenolic contents, Cholesterol, Amino acid.

\begin{tabular}{lll}
\hline Estimation & Pulp $(\mathbf{m g})$ & Seed $(\mathbf{m g})$ \\
\hline Phenolic contents & $34.2 \pm 5.4$ & $34.1 \pm 2.5$ \\
Cholesterol & $0.2 \pm 0.08$ & $0.2 \pm 0.07$ \\
Amino acid & $42.1 \pm 0.6$ & $35.3 \pm 0.2$ \\
\hline
\end{tabular}

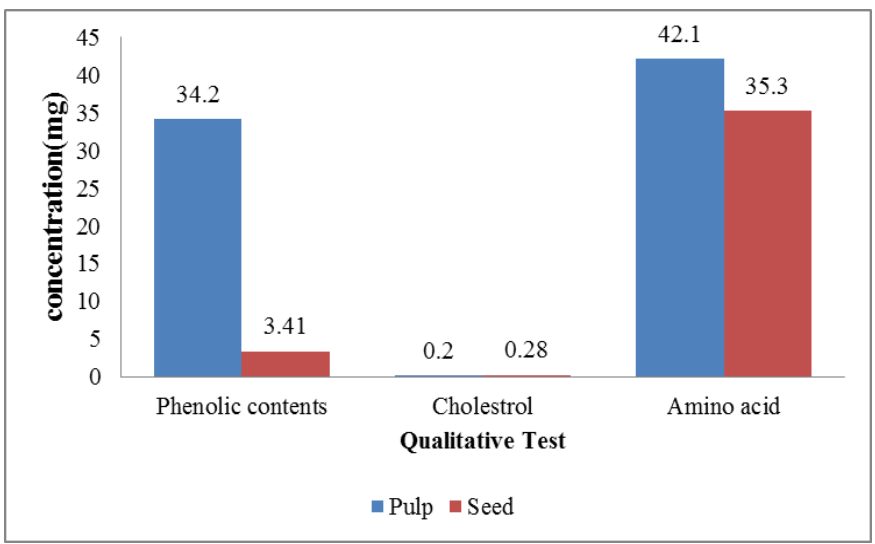

Graph 2. From graph-2: Cholesterol content was very low in both pulp and seed while the phenolic and amino acid contents were much greater in comparison to seed.

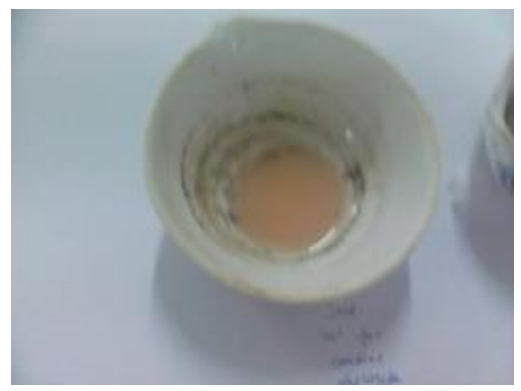

Fig. 9: Cardiac glycoside powder. 
Table 4. The results of estimation of alkaloids, flavonoids, cardiac glycoside and tannins in avocado.

\begin{tabular}{lll}
\hline Estimation & Pulp $\mathbf{( m g )}$ & Seed $(\mathbf{m g})$ \\
\hline Alkaloids & $3.1 \pm 0.8$ & $1.8 \pm 0.08$ \\
Flavonoids & $3.4 \pm 0.2$ & $0.68 \pm 1.5$ \\
Cardiac glycoside & $0.4 \pm 0.1$ & $0.68 \pm 1.2$ \\
Tannins & $0.2 \pm 0.1$ & $0.09 \pm 0.5$ \\
\hline
\end{tabular}

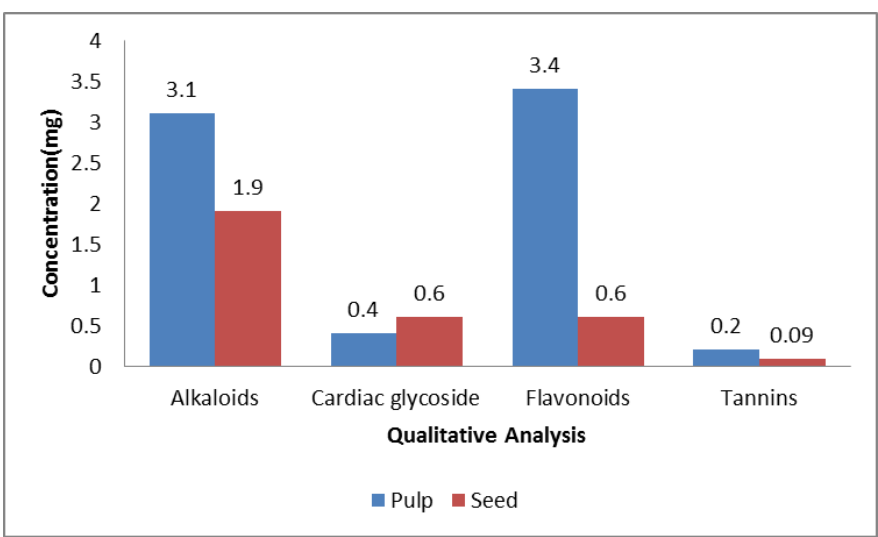

Graph 3. Alkaloids, Flavonoids, tannins, the pulp showed higher amount of concentration. In cardiac glycoside, the seed showed lesser amounts.

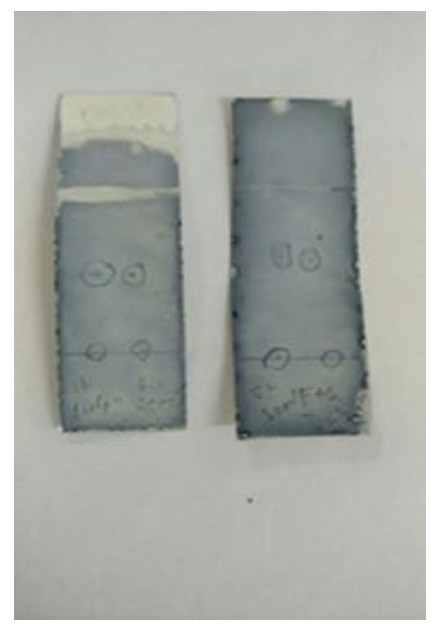

Fig. 10: Chromatogram showing the presence of phenolic compound

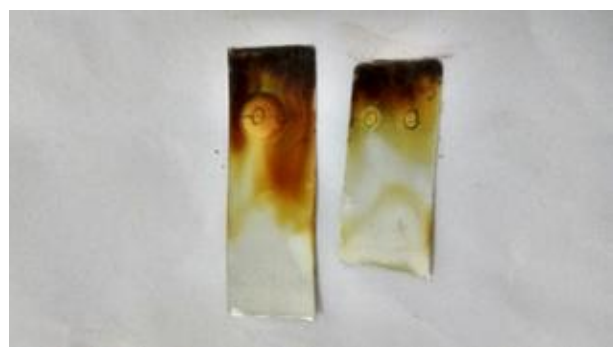

Fig. 11: Shows the chromatogram for presence of phytosterols

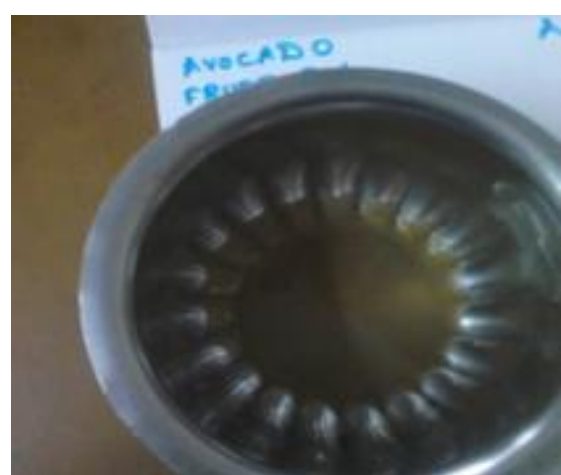

Fig. 12: Pulp oil of avocado.

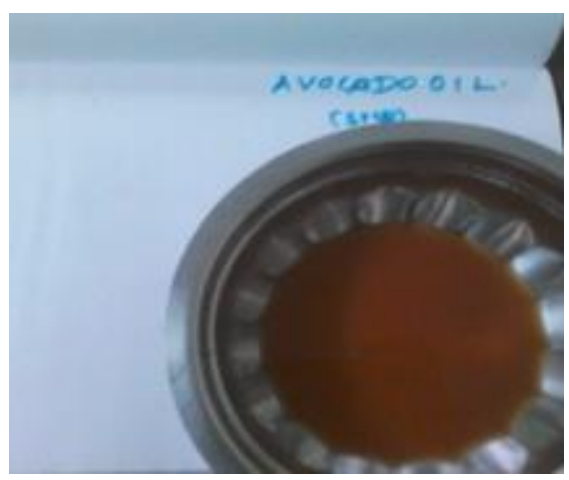

Fig. 13: Seed oil of avocado.

Table 5. The results for the lipid profile of oil extracted from avocado.

\begin{tabular}{lll}
\hline Estimation & Pulp $(\mathbf{m g})$ & Seed $(\mathbf{m g})$ \\
\hline Acid value & $515 \pm 5$ & $235 \pm 5$ \\
Cholesterol & $850 \pm 5$ & $350 \pm 4$ \\
Saponification value & $360 \pm 2.5$ & $350 \pm 1$ \\
Iodine number & $900 \pm 0.1$ & $800 \pm 0.1$ \\
Fatty acid & $515 \pm 5$ & $221 \pm 4$ \\
\hline
\end{tabular}

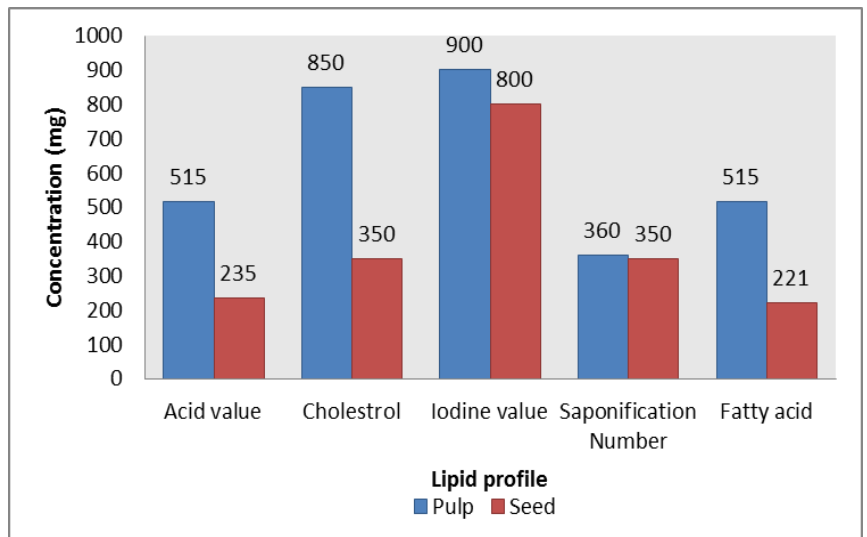

Graph 4. From Graph-4, the Pulp showed high concentration of Cholesterol, Acid value, Iodine value The Saponification value was almost the same for pulp and seed. 


\section{Cytotoxicity test}

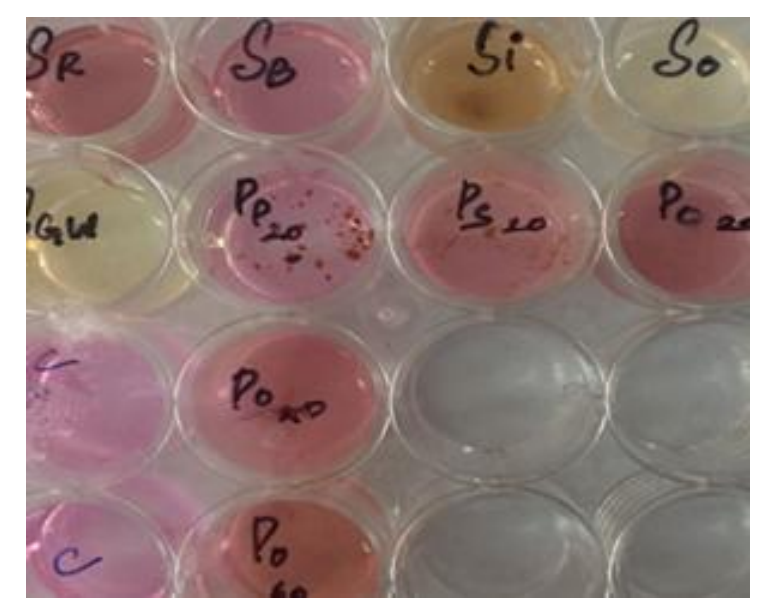

Fig. 14: Titre plates showing cytotoxicity studies.

Table 6. Cytotoxicity studies of avocado.

\begin{tabular}{llll}
\hline Samples & $\mathbf{2 0} \boldsymbol{\mu l}$ & $\mathbf{4 0} \boldsymbol{\mu l}$ & $\mathbf{6 0} \boldsymbol{\mu l}$ \\
\hline Pulp & $92.8 \%$ & - & - \\
Seed & $41.8 \%$ & - & - \\
Pulp oil & $35 \%$ & $40 \%$ & $42.5 \%$ \\
\hline
\end{tabular}

From the results obtained for cytotoxicity studies, it was seen that the pulp, seed, and oil were good cytotoxic agents. Pulp was showing the highest of $92.8 \%$ while oil shows effective cytotoxicity in 20 , 40 , and $60 \mu 1$ of sample.

\section{Conclusion}

Various parameters were analysed on extracts of avocado seed and pulp. Macromolecules such as Carbohydrates, Protein, and Fatty acids showed appreciable concentration in both avocado seed and pulp. Fatty acid showed higher concentration while proteins showed the least concentration in pulp and seed; carbohydrates were present in the same concentration. Phytochemical analysis showed the presence of alkaloid, flavonoids, saponins, tannins which were also quantified. Presence of Phenolic compounds, cholesterol and amino acid were determined. Amino acid and phenolic content showed higher concentration in case of pulp and seed whereas cholesterol was present in small amount. Oil was extracted from both avocado pulp and seed. Lipid profile analysis conducted showed significant results for the estimation of cholesterol, fatty acid, Iodine number, Saponification number. Iodine number was high in pulp and seed. Fatty acid value and acid value were the same in pulp and seed. Saponification number was also the same for seed and pulp. Cytotoxicity studies done with Avocado pulp and oil showed 35\%,40\%, and $42.5 \%$ cytotoxic effect at 20,40 and $60 \mu$ l with pulp showing the highest toxicity of $92.8 \%$. In conclusion, Avocado is a whole some nutritive fruit which is not much explored but contains a number of benefits for the consumer.

\section{Conflict of interest statement}

Authors declare that they have no conflict of interest.

\section{References}

Arpaia, M., et al., 2006. Avocado Post harvest Quality. California Avocado Research, 13(3), 143-155.

Bob Bergh, 1992. Nutritious Value of Avocado. California Avocado Society Proc. Second World Avocado Congress. 10(3), 25-35.

Huang, T. H., et al., 2002. An evaluation of the cytotoxic effects of orthodontic bonding adhesives upon a primary human oral gingival fibroblast culture and a permanent, human oral cancer-cell line. J. Biomed. Mater. Res. 63(6), 814-21.

Indumathi, P., Vijayalakshmi, K., 2014. Comparative study on physico and phytochemical analysis of Persea americana and Actinidia deliciosa. Scient. Res. Publ. 16(4), 2250-3153.

Santos, M.A.Z., 2013. Influence of preparing process of pulp and extraction method in the oil yield of Fortuna avocado. Higiene Alimetar. 27(3), 3776-377.

Mudasir Sultana et al., 2012. Quantitative analysis of total phenolic, flavonoids and tannin contents in acetone and n-hexane extracts of Ageratum conyzoides. Int. J. Chem Tech. 27(4), 15-22.

Nathaniel Owusu Boadi et al., 2015. Phytoconstituents, antimicrobial and antioxidant properties of Persea americana Mill. Med. 
Plants Res. 9(36), 933-939.

Tango, 2015. Phytochemical and chemical characterization of avocado fruits aiming its potential for oil extraction. Rev. Bras. Fruticult. 26(2), 17-23.
Wang, W., 2014. Antioxidant capacities, procyanidins and pigments in avocados of different strains and cultivars. Food Chem. 35(6), 921-925.

\section{How to cite this article:}

Sri Padmapriya, R., Singh, A. R. J., 2018. A study on the extraction of essential oil from avocado and its properties. Int. J. Curr. Res. Biosci. Plant Biol. 5(6), 76-85.

doi: https://doi.org/10.20546/ijcrbp.2018.506.008 